$$
\text { PART II }
$$

\title{
Translation of The Clarion of Syria
}





\section{Clarion I}

Beirut, September 29, I860

\section{Countrymen,}

News of the spell of atrocities and abominations committed this summer by the troublemakers in our midst has reached the corners of the Earth. All over the civilized world, it has drawn pity and gloom, on one hand, and anger and wrath, on the other. Yet, we witness charity pour in from all sides to help the needy. Armies from every land are also heading our way to protect the weak and to punish the guilty and the aggressor.

All too often we have noticed how the victorious faction boasts about its deeds, declaring "we have satisfied our honor" and the like. ${ }^{2}$ What the victors do not seem to realize is that the civilized world has nothing but disgust, contempt, and rage for what they take pride in. It regards their deeds as the work of savage barbarians devoid of humanity, character, chivalry, and faith, the work of thieves and bandits. That is why the civilized world has now joined forces to unleash the worst of punishment on the oppressors and to teach them a lesson. At the same time, we see the majority of the vanquished fall under the illusion that the armies came only to help them seek revenge and sanction the looting and bloodletting of their adversaries. This is nothing 
but a distortion of the true intentions of the Great Powers. If this wronged faction plans to act with this interpretation in mind, they would expose themselves to rage and would deserve harsher punishment than the victors. Sympathy for them would turn into harsh treatment, and as a result they would be subject to great harm.

Let the victors know that the time for their bravery and prowess has passed, and that their brandishing of arms has become impermissible and unacceptable. The only way forward then is to trust in their government and the friendly powers that are disembarking here to restore peacefulness and security in their quarters. They need to wait patiently for the philanthropic efforts that these states have agreed upon, for these efforts will duly take into account the opinions of the people and require their assistance.

It is a blatant mistake for the victorious faction to run away and leave their hometowns under the illusion that they can escape the punishment they deserve. Running away can only lead to the breakup of families and the ruin of the country. Moreover, it causes undue suspicion toward the innocent among the runaways. Neither the victorious party nor anyone else should assume that these states sent their representatives to take the side of one group over another, or to protect a certain group or avenge another just because they are Christian or non-Christian. As far as we know, they came only to protect the rights of man and to enforce the principles of justice and rule of law. No innocent group needs to be afraid, and we have no evidence that collective accusations will be levied on any one faction.

And so, countrymen, the destruction and damage that afflicted our land are unparalleled in historical chronicles. Most of you are well aware of the reasons behind this destruction. 
This pains all the more the heart of every eyewitness and patriot. Even if this destruction appears to affect only some of you, it is, in fact, a matter affecting all. Any loss incurred comes out of the national treasury, and the loss of every soul is the loss of society as a whole.

\section{Countrymen,}

You drink the same water, you breathe the same air. The language you speak is the same, and so are the ground you tread, your welfare, and your customs. You may still be intoxicated from drinking your compatriots' blood, or disoriented by the calamities you have suffered. But very soon you must wake up from this stupor and realize the meaning of my advice and where your welfare lies. This is what I intend to convey to you here. I hope that I can continue writing to you, and I ask God to guide you toward knowing your own good and the good of your country. May your hearts embrace the teachings and principles of the faith you believe in. And may God preserve you.

From a patriot 